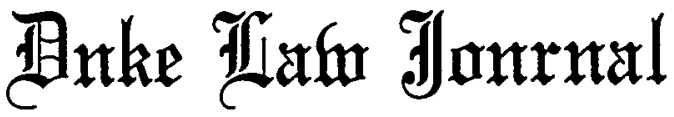

VOLUME 1979

JUNE

NUMBER 3

\section{THE IMPACT OF FIDUCIARY STANDARDS ON FEDERAL TAXATION OF GRANTOR TRUSTS: ILLUSION AND INCONSISTENCY}

\author{
JoHN L. PescheL*
}

When applied to inter vivos trusts, federal income, estate, and gift tax rules often produce uncoordinated-and at times unpredictabletax consequences. Recent revisions of the Code left virtually ${ }^{1}$ untouched the maze of sections that determine the tax status of inter vivos transfers in whicli the grantor retams soine degree of benefit or control. ${ }^{2}$ From these rules, as suppleinented by a generation of regulatory,

* Professor of Law, New York University; B.B.A. 1957, University of Minnesota; J.D. 1961, University of Michigan; Member of the New York bar.

THE FOLLOWING CITATIONS WILL BE USED IN THIS ARTICLE:

J. Peschel \& E. Spurgeon, Federal Taxation of Trusts, Grantors, and BenefiCIARIES (1978) [hereinafter cited as J. PESCHEL];

R. Stephens, G. Maxfield \& S. Lind, Federal Estate \& Gift Taxation (4th ed. 1978) [hereinafter cited as R. STEPHENS];

Pedrick, Grantor Powers and the Estate Tax: End of an Era?, 71 Nw. U.L. REv. 704 (1977) [hereinafter cited as Pedrick].

1. The principal exception was the Iegislative reversal of United States v. Byrum, 408 U.S. 125 (1972). See text accompanying notes 133-36 infra.

2. Briefiy, sections 67 I-679 of the 1954 Code govern the income tax consequences of "grantor trusts." Under section 673 , the grantor is treated as owner of the trust for income tax purposes if he retains a reversionary interest that can take effect within ten years of the transfer. Subject to detailed exceptions, section 674 provides that the grantor will be treated as owner of any portion of the trust over which he or a "nonadverse party," see I.R.C. $\$ 672(a)$, (b), has a power to dispose of the beneficial enjoyment. I.R.C. § 674(a); Treas. Reg. § 1.674(a)-1(b) (1960). If administrative control of the trust can be exercised primarily for the benefit of the grantor rather than the beneficiaries of the trust, section 675 treats the grantor as owner of the trust. Treas. Reg. $\S 1.675-1$ (a) (1960). The types of administrative powers that trigger the operation of the rule are detailed in section 675 . Unless exercisable only after a ten-year period, a power in the grantor or in a nonadverse party to revest the corpus in the grantor will cause the income generated by the corpus to be included in the grantor's taxable income under section 676. "Under section 677, the 
administrative, and judicial interpretations, the estate planner is supposed to be able to advise his client about the degree of benefit in or control over the trust that a grantor of an inter vivos trust may retain without sacrificing the income and estate tax advantages associated with such trusts. ${ }^{3}$

Grantors possess broad discretion in structuring the forn of an inter vivos trust transfer. ${ }^{4}$ Exercise of that discretion produces a predictable spectruin of tax results between the extremes of the grantor clearly continuing to be taxed on the trust income and the value of the trust assets clearly being included in his gross estate and the grantor clearly not being taxed on the trust income and trust assets clearly being excluded froin his gross estate. Grantors of trusts falling between the two extremes often endured uncertainty concerning tax consequences until patterns of interpretation in the inarginal areas became settled. Developinent of a substantial level of consensus concerning tax results for common types of inter vivos trusts may have discouraged congressional intervention. Nevertheless, important problems with these rules persist: coordination between the estate and gift tax rules is imperfect, ${ }^{5}$ and coordmation between the two transfer taxes and the incoune tax is even worse.

Of critical importance is the fact that the tax results in a particular situation often depend upon both the degree of fiduciary involvement

transferor is treated as the owner of the trust for income tax purposes so long as the income is (or may be) paid to him (or to his spouse)." D. KaHN \& L. WAggoner, Federal Taxation of GifTs, TRusts AND Estates 489 (1977).

The principal estate tax sections are I.R.C. $\$ \$ 2036-2038$. Section $2036(a)(1)$ includes within the grantor's gross estate property in trust if the grantor retained for his life, for any period not ascertainable without reference to his death, or for any period that does not in fact end before his death the possession, enjoyment of, or right to the income generated by the property. If the grantor retains the right (alone or in conjunction with another) to affect the beneficial enjoyment of the property for the periods described above, section 2036(a)(2) will operate to include the property in the grantor's gross estate. Under section 2037, if possession or enjoyment of property transferred by the decedent can only be obtained by surviving the decedent, if the decedent has retained a reversionary interest in the property, and if the value of the reversionary interest exceeds five percent of the value of the entire property, then the property is included in the grantor's gross estate, See Treas. Reg. $\$ 20.2037-1$ (a) (1958). Section 2038(a)(1) provides for inclusion in a grantor's estate of property over the enjoyinent of which he has at time of death power to alter, amend, revoke or terminate.

I.R.C. $\$ 2501$ imposes the gift tax on gratuitous transfers of property. However, the gift inust be "complete" for the tax to be imposed, that is, the donor must have "so parted with dominion and control as to leave in him no power to change its disposition . . . " Treas. Reg. \$25.25112(b) (1958).

3. See generally J. Peschel \4.01.

4. See A. Scott, Abridgement of the Law of Trusts $\$ 4$ (1960).

5. Although various studies of the transfer tax system agree on the need for reconciliation, see D. KAHN \& L. WAGGONER, supra note 2, at 622-25, Congress expressly declimed to do so in 1976. H.R. Rep. No. 1380, 94th Cong., 2d Sess. 12 (1976). 
in the grantor benefit or control and the identity of the trustee. The primary question considered in this Article is whether various pohicy considerations ${ }^{6}$ are properly reflected in the role that fiduciary limitations on the discretion of the trustee have in the existing rules for federal taxation of grantor trusts. Generally speaking, grantor trusts raise the question whether a transfer is sufficiently complete to remove trust incoine from the grantor's gross incoine and trust assets from his gross estate. ${ }^{7}$ Tentative answers to the basic question can, of course, be made only after an analysis of the federal tax consequences associated with typical types of grantor trusts. Accordingly, Part I of this Article considers the grantor's vuhierability to adverse tax results with trusts involving possible personal benefit for the grantor. Part II then reviews the tax dangers of trusts in which the grantor has reserved no personal benefit but does have continuing direct or indirect control of the beneficial enjoyinent of the trust. ${ }^{8}$ Part III begins with a statement of the relevant policy considerations, followed by an overview of the existing rules and by two alternative schemes of nodification designed to ahgn inore effectively the tax results of grantor trusts with these policy considerations.

\section{GRANTOR BENEFIT}

Two inportant reasons for creatimg irrevocable inter vivos trusts are the reduction of estate taxes and the reduction of income taxes. ${ }^{9}$ Retention of benefit by the grantor, however, may well result in a gift that is inter vivos in form but testainentary in reality. Thus, if the grantor retains beneficial enjoyinent for his life, the practical result is similar to that when the grantor devises the property: in both situations, the grantor lias the benefit of the property until his death, at which time the enjoyment of the property passes to another. A similar situation exists

6. See text preceding and accompanying notes 142-43 infra.

7. Typically, the tax cost to the grantor who has protected his estate and income tax position will be federal gift tax, which alone will not always deter such a transfer, see J. PESCHEL \ 1.03 .

8. See generally J. Peschel II 4.01-6.04; R Stephens II 4.08-4.10; Lewis, Powers Retained by the Settlor of a Trust: Their Income, Estate and Gift Tax Treatment, 5 Real Prop. Prob. \& TR. J. 1, 1-20 (1970).

Parts $I$ and $I I$ are limited to considerations of federal estate, gift, and income tax consequences. While estate planners cannot ignore state and foreign tax rules, their importance is less for reasons explained in J. Peschel 1 1.04. The new federal tax on generation-skipping transfers, I.R.C. $\$ \S 2601-2622$, will not be considered because it does not have major direct impact on the grantor's tax problems. Nonetheless, grantor trusts must be reviewed for generation-skipping tax consequences that will be borne by the trust and the beneficiaries. In general, fiduciary standards and identity of trustee can be important, see generally J. PESCHEL If 10.06[C].

9. The Tax Reform Act of 1976, Pub. L. No. 94-455, 90 Stat. 1893, reduced but did not eliminate the estate tax advantages of lifetime gifts, J. PESCHEL If 2.01. 
in the case of indirect benefit to the grantor where the risk of adverse tax consequences are more likely to escape attention of even professional advisers. ${ }^{10}$

\section{A. Nondiscretionary Trusts.}

Even though a client has been persuaded by his estate planning adviser to make substantial imter vivos gifts (probably in trust form), he may well resist a transfer that entirely excludes him from any posttransfer benefit froin the property. For example, a fifty-five year old executive $(G)$, who has "excess" assets appropriate for inter vivos gifts, may legitimately fear that retireinent, serious illness, or unpredictable economic developments could make an irrevocable hifetime gift without reserved benefit a mistake. With such concerns, $G$ may press for an irrevocable trust in the following form: income payable to him for life, remainder to his children. (Example 1). ${ }^{11}$ Unfortunately, this response to the estate planner's advice to make substantial hifetime gifts is clouded by a gloony tax picture. The date-of-death value of the trust property will be included in $G$ 's gross estate, ${ }^{12}$ and the irrevocable remainder interest in favor of his children will constitute a gift for gift tax purposes. ${ }^{13}$ Moreover, $G$ remams taxable on the current trust mcome, not in his capacity as beneficiary but as grantor of a trust with a retained life estate. ${ }^{14}$

Has $G$ achieved any tax advantages by such a trust transfer? The payment of gift tax at the time of creation and the subsequent inclusion of the trust in his gross estate does not trigger a double tax, because the tentative estate tax determined under section 2001(b)(1) is reduced by the amount of the gift tax. ${ }^{15}$ Except for gifts made within three years prior to death, the prepayment of the estate tax in the form of the prior

10. J. Peschel $\prod 4.01$, at 4-3.

11. Alternatively, $G$ 's wife would receive the income for life, then income would be payable to $G$ for life. The estate tax treatment of this variation is described in Treas. Reg. $\S 20.2036-$ 1(b)(1)(ii) (1958). The income tax consequences are identical to those in Example 1, even during the period when $G$ 's wife is receiving the income. I.R.C. $\$ 677$ (a).

12. 1.R.C. \& 2036(a)(1).

13. Only the value of the remainder interest determined by actuarial methods will constitute a gift. Treas. Reg. $\S \S 25.2511-1$ (e), 25.2512-5(d) (1958).

14. The normal trust-beneficiary income tax rules, I.R.C. $\S \S 651-662$, are applicable only to the extent that the grantor is not treated as owner of a portion of the trust under sections 671-677. In this situation $G$ would be taxed under section 677(a)(1). Treas. Reg. $\S 1.671-2$ (d) (1960).

15. Under I.R.C. $\$ 2001$ (b), the gift tax value of the remainder interest is excluded from the term "adjusted taxable gifts" but the date of death value of the trust is included im the "taxable estate." However, I.R.C. $\$ 2001$ (b)(2) allows a reduction in the tentative tax for all gift tax paid on transfers after December 31, 1976. With respect to gifts prior to January 1, 1977, I.R.C. $\$ 2012$ allowed a credit against the estate tax for the gift tax attributable to a lifetime transfer included in the gross estate. 
gift tax now allowed as a credit against the estate tax does offer the advantage of removing from $G$ 's gross estate the value of the property used to pay the gift tax. ${ }^{16}$ Furthermore, income realized by the trust that is allocable to trust primcipal, and consequently not distributable to $G$, will be taxable to thie trust rather than to $G .{ }^{17}$ Froin a policy standpoint, the adverse tax results outlined above flow naturally from the substantial and unqualified "rights" retained by $G .{ }^{18}$

\section{B. Limited Discretionary Trusts.}

1. Third-Party Trustee. Instead of retaining all the income from the trust for his life, the grantor may decide to retain only that amount designated by the trustee in accordance with an ascertamable standard, such as "necessary for support and maintenance." (Example 2). Despite the modification of $G$ 's interest from an absolute one to one subject to "objective" facts to be determined by the trustee, the adverse tax consequences associated with the nondiscretionary trust will probably not be avoided. The controlling consideration is $G$ s right to compel distributions that are necessary for his support and inaintenance. ${ }^{19}$ In other words, since the trustee's discretion is limited by an objective standard, the beneficiary $(G)$ can brimg an action to require compliance with that standard. ${ }^{20}$ Practically speaking, the third-party trustee's decisions probably will be final, either because $G$ is satisfied or because of the traditional deference given by the courts to reasonable exercises of discretionary trustee powers. ${ }^{21}$ The legal theory, however, causes the transfer to be deemed at least partially incomplete for tax purposes.

(a) Estate tax consequences. With respect to Example 2, important deviations from the precise tax results of Exainple 1 could be de-

16. Under I.R.C. $\S 2035(\mathrm{c})$, the gross estate is increased by the amount of the gift tax paid on the gifts made within three years prior to the decedent's death.

17. For purposes of I.R.C. $\S 677(a), G$ is treated as owner of only the ordinary income portion. Treas. Reg. \& 1.671-3(b)(1) (1960).

18. The government's position on the estate tax aspect was temporarily derailed by the Supreme Court's dubious interpretation of the early estate tax law in May v. Heiner, 281 U.S. 238 (1930).

19. Unlike the situation in which the beneficiary of the power subject to the ascertamable standard is a party other than the grantor, see text accompanying notes 110-14 infra, the introduction in Example 2 of trustee discretion to determine the amount and the timing of a distribution is not determinative of tax consequences.

20. Letter Ruling 7833062, Fed. Est. \& GIFT TAX REP. (CCH) ๆ 12,179 (May 18, 1978).

21. 3 A. SCOTr, THE LAW OF TRUSTS $\S 187$ (3d ed. 1967). The practical problems associated with judicial review are illustrated in $I n$ re Trust of Salimes, 43 Wis. $2 \mathrm{~d} 140,168$ N.W.2d 157 (1969) where the Supreme Court of Wisconsin split three ways on the question whether a trustee could consider the type of higher education for which the beneficiary was seeking a trnst distribution. 
fended by the taxpayer. If the governing factor for inclusion in $G$ 's gross estate is the right to only such amounts of trust incoine as are necessary for his support, $G$ 's executor should be allowed to prove that, given $G$ 's circumstances, some portion of the trust incone would not have been distributed for the designated purpose. While there is authority to support such an analysis, ${ }^{22}$ the problems of proof are considerable and the burden of proof rests on the executor to demonstrate what portion less than one hundred percent should be included. ${ }^{23}$ The type of trust suggested in Example 2 should never be created in reliance upon the executor's ability to defend partial inclusion, except in cases of substantial transfers of property, the incoine from which clearly and significantly exceeds $G$ 's support needs.

(b) Income tax consequences. The grantor's position that the entire trust incoune should not be taxable to him is weaker than his argument that the entire trust should not be included in his gross estate because of different statutory language. Section 677(a) imposes incoine tax on the grantor for trust income that "is, or, in the discretion of the grantor or a nonadverse party, or both, may be-(l) distributed to the grantor or the grantor's spouse ...."24 The third-party trustee who has no beneficial interest in the trust will constitute a nonadverse party. ${ }^{25}$ Moreover, the "may be" language in section 677(a) suggests that uncertain or contingent access to the trust income does not foreclose the grantor from being taxed on all of it. On the other hand, it is clear that a grantor who is entitled by express provision in the trust instrument to only one-half of the trust income would be taxed on only that one-half. ${ }^{26}$ Where the grantor's right is limited by an objective standard such as "support or maintenance," he should be entitled to offer proof that the standard forecloses distribution of some portion of the trust income to him. However, there is some authority that suggests the taxpayer's interpretation of section 677 (a) on this point will not be accepted. ${ }^{27}$ Aside from practical problems of proof, which would be

22. See Estate of Marvin L. Pardee, 49 T.C. 140, 149 (1967) (taxpayer aided by government concession that entire trust could not be used for support of grantor's dependents). See also Estate of Gokey, 72 T.C. No. 63 (July 30, 1979); Rev. Rul. 79-109, 1979-14 1.R.B. 9 (relating to a transferor's right to use transferred property for a portion of each year).

23. Commissioner v. Dwight, 205 F.2d 298, 302 (2d Cir. 1953).

24. I.R.C. $\$ 677$ (a). The comparable estate tax provision states in part that the estate includes the value of property over which grantor "has retained for his life . . the possession or enjoyment of, or the right to the income . . ." I.R.C. $\$ 2036(a)(1)$.

25. A trustee, as such, is not an adverse party. Treas. Reg. $\$ 1.672(a)-1$ (a) (1960).

26. Treas. Reg. $§ 1.671-2(a)(3)$ (1960) (relating to "undivided fractional interests").

27. E.g., Barker v. Commissioner, 25 T.C. 1230 (1956); Koehrer v. Commissioner, 14 T.C.M. (P-H) $\uparrow 45,068$, at 235 (1945). In Barker, the result is more easily defended because the trustee's 
common to both the estate and income tax aspects in this area, a potential conflict in basis rules between the two taxes may exist here.

(c) Gift tax consequences. In the context of Exainple $2,{ }^{28}$ the governunent has given its most explicit consideration of the "ascertamable standard" analysis in the regulations interpreting the general statutory language imposing a tax on a transfer of property by gift. According to the regulations, a gift is incoinplete to the extent that the "exercise of the trustee's power in favor of the grantor is limited by a fixed or ascertainable standard ... enforceable by or on behalf of the grantor "29 However, these regulations allow a reduction in the value of the gift only by the amount of the "ascertainable value" of the grantor's rights. Thus, the taxpayer faces the serious possibility of failure to satisfy the burden of proof, which in Example 2 would result in a gift tax inposed on the full value of the property. ${ }^{30}$ Failure to supply the necessary proof regarding the ascertainable portion might result in complete taxpayer defeat in each case, that is, the full value of the trust being subject to both the gift and the estate tax..$^{31}$

2. Grantor as Trustee. We have seen that when the trustee is an independent third party, the grantor who conditions his right to income upon the trustee's evaluation of facts according to an ascertainable standard inay, in theory, limit his tax liability. ${ }^{32}$ Does changing the identity of the trustee alter these tax consequences?

(a) Estate tax consequences. When the grantor is also the trustee, it is unclear whether his "right" to distribute to himself only amounts allowed by the objective standard would prevent inclusion in his gross estate of the "excess" portion of trust. ${ }^{33}$ If the grantor is also the trustee

power to make distributions to the grantor was "almost without limit." 25 T.C. at 1234. In Koehrer, the grantor lost for one tax year on burden of proof as to the limits of portion available for his benefit. In the other tax year, though the trustee's power was confined to a support and maintenance standard, the court held that entire trust income was taxable to the grantor, "whether or not so used." 14 T.C.M. at 237.

28. See text preceding note 19 supra.

29. Treas. Reg. $\$ 25.2511-2$ (b) (1958). The definition of "ascertamable standard" is explored in Treas. Reg. $\S 25.2511-\mathrm{l}(\mathrm{g})(2)(1958)$.

30. Treas. Reg. $\$ 25.2511-1$ (e) (1958).

31. With respect to relief from double taxation, see note 15 supra.

32. Of course, the difficulty of proving the amount of the trust that is not subject to the grantor's right renders the theoretical advantage largely speculative. See text accompanying notes 23 \& 30 supra.

33. The excess portion is the percentage of the trust that uuder the ascertainable standard could not benefit the grantor. 
the entire trust might be subject to estate tax. ${ }^{34}$ Such a result would flow from a distrust of the grantor's objectivity in applying the ascertainable standard. At the very least, a persistent and significant deviation by $G$ from the ascertainable standard would support court intervention on behalf of the renaindermen. When the grantor is the trustee, an arms-length analysis seems abstract, a fact that surely encourages the government to resolve the estate tax issue on the basis of practical power, rather than on the basis of theoretical fiduciary limitations to the grantor's enjoyment of the property.

(b) Income tax consequences. The grantor's vulnerability under section 677 (a) depends in the original Example 2 on a broad reading of the "Inay be" language of section 677(a), rather than on the identity of the trustee. $G$ 's assuinption of the role of trustee inay not substantially increase the risk that he is taxable on the entire trust income, since the income tax liability may not be predicated on the linitations upon the trustee's fiduciary duty.

(c) Gift tax consequences. The complementary gift tax problem is not expressly resolved by the authoritics. Certainly, the principal example in the regulations anticipates a reduction in the value of the gift by the ascertainable value of the retained grantor benefit where the trustee is a third party. ${ }^{35}$ On the other hand, the reduction in the value might be increased to an anount equal to a full life estate for $G$, when $G$ is also the trustee. ${ }^{36}$ Such a result would rccognize $G$ s practical power to benefit himself rather than theoretical fiduciary hinitations.

3. Nongrantor Beneficiary as Trustee. Suppose that instead of appointing himself as the trustee, the grantor appoints one of his children-the reinainderinen of the trust-as the trustee.

(a) Estate tax consequences. In Example 2, when an independent third party is the trustee, the entire trust will be included in the grantor's gross estate unless the grantor's estate can prove that there is an "excess" portion that would not have to be used to satisfy the grantor's

34. Under section 2036(a)(2), the grantor cannot have the power to designate the person who will possess or enjoy the property. See National Bank of Commerce v. Henslee, 179 F. Supp. 346 (M.D. Tenn. 1959) (court disregarded probability that grantor, who was not trustee, would not exercise a power to revoke).

35. Treas. Reg. $§ 25.2511-2$ (b) (1958).

36. Compare the first and second sentences of Treas. Reg. $\$ 25.2511-2$ (c) (1959). The reference in the second sentence to ascertainable standards may apply only to cases in which the gift is complete because the standard relates to the control by the grantor of benefit to third parties (not including the donor). 
interest. ${ }^{37}$ When the grantor appoints himself trustee, the likelihood of one hundred percent inclusion in his gross estate increases, because of the grantor's power, albeit in a fiduciary capacity, to distribute income to himself. ${ }^{38}$

When the grantor appoints a remainderman as trustee in Example 2 , the estate tax result will be the saine as when an independent third party is the trustee. Having an adverse party as the trustee does not affect the grantor-benefit analysis because the trustee remains under a fiduciary duty to distribute to the grantor if the conditions of the ascertainable standard are met, even if he does have a conflict of interest. Under section 2036(a)(2), the grantor-power analysis does not come into play, because the grantor himself is not a trustee. ${ }^{39}$

(b) Income tax consequences. The adverseness of the trustee's imterest is expressly relevant under section 677(a). Since a child of $G$ would have an adverse interest in the exercise of the limited discretionary power contemplated in Example 2, it is much easier to accept the argument that section 677(a) does not apply to that portion of the trust (if determmable) that is not necessary to supply imcome to meet the grantor's right to support payments. Stated differently, the tax avoidance potential is less where the administration of the objective standard rests with a person having an interest in conflict with a broad or erroneous interpretation of the standard. Both the legal right of the grantor to only that portion necessary for his support and the practical self-interest of the trustee suggest that autoinatically taxing $G$ on the entire trust income is not appropriate. The soundness of this conclusion is, of course, undermined by questions about the viability of the adverse interest test on the facts of Example 2, where the child-trustee may subordinate self-interest to considerations of family harmony or respect for the parent-grantor. But in the abstract, the apphicability of section 677(a) could be said to depend solely on a determination of $G$ s legal rights (that is, the portion of the trust necessary for support payments), making the identity of the trustee, who is legally bound by the standards imposed by the trust instrument, irrelevant.

(c) Gift tax consequences. For gift tax purposes, the "substantial adverse interest" of the power holder is relevant only if the donor

37. See text accompanying notes $22-23$ supra.

38. See note 34 supra and accompanying text.

39. Treas. Reg. $\$ 20.2036-1$ (b)(3) (1958). However, if the grantor reserves the unrestricted power to remove or to discharge the trustee and to appoint himself, then the grantor is considered to have the power of the trustee over the distribution of income to himself. Id.; Mathey v. United States, 491 F.2d 481 (3d Cir. 1974); see J. Peschel I 5.04. 
shares the power with such person. ${ }^{40}$ Therefore, in Exainple 2, $G$ 's child as sole trustee would not change the result that a reduction in the value of the gift is allowed for the amount representimg the grantor's retained interest measured by the ascertainable standard. ${ }^{41}$

4. Limited Discretionary Trusts-A Summary. On balance, the persistence of the adverse estate and income tax consequences to the grantor in Example 2 seems appropriate. The overriding legal right of $G$ to support payments ${ }^{42}$ from the trust should result in inclusion of at least a portion of the trust value at date of death in his gross estate, and in continued taxation on imcome from at least that portion of the trust, the income from which is necessary to satisfy his right. ${ }^{43}$ The complementary reduction in the value of the gift to the extent of the value of the retained benefit subject to an ascertamable standard is also correct. The fact that a fiduciary (other than the grantor) is directly involved im the determmation of the actual distributions to the grantor should neither increase nor decrease the estate and income tax burden. The grantor's legal right to support payments should prevail over practical doubts about the imdependence and objectivity of the third-party trustee. In truly margmal situations, the government and courts might well allow these factors to influence their judgment concerning the quality of the taxpayer's presentation on the allocation issue. Certainly, we should be cautious about miporting as a matter of law the adverse party test into the resolution of the taxpayer's right to limit estate and income taxation to an identifiable portion of the trust necessary for his support payments. ${ }^{44}$ It would not be unfair to draw the dividing lime between the third party and the grantor as trustees. At

40. Treas. Reg. \$ 25.2511-2(e) (1958).

41. See note 35 supra and accompanying text.

42. See note 19 supra and accompanying text.

43. Section 677(a) should not be interpreted $m$ a way that prevents the taxpayer from arguing that some portion of the trust is not required for support and therefore is not available to supply a grantor benefit. The net result might be to confine grantor's income tax exposure to approximately the same amount he would be taxed in his capacity as beneficiary, which seems appropriate given the limitation imposed on his rights to benefit from the trust. One practical difficulty associated with this approach is the recurring feature of the income tax issue (as compared to the one-time estate tax problem). Assuming that a reasonable estimate of the excess portion not needed for the required support payment can be supplied, is the allocation problem to be reviewed annually? In general, the government should be satisfied with conservative estimates of the excess portion andishould expect reconsideration only in the event of a fundamental change im the grantor's support needs or after a significant lapse of time.

44. Initially it would seem that the adverse party test cannot be avoided under the express language of section 677(a). As suggested previously in the text, the income attributable to the "exeess" portion could be excluded on the theory that not even the nonadverse party trustee has discretion to distribute to the grantor income from that portion. 
least, a grantor wishing to establish a trust in the form outlined in Example 2 with the expectation of bona fide coinpliance with the objective standard would have an ample field of trustee candidates in most situations.

\section{Broad Discretionary Trusts.}

The key to the mclusion of some portion of the limited discretionary trust (Example 2) in $G$ s gross estate and continued treatment of $G$ as owner of some portion of the trust for income purposes is $G$ s enforceable riglt to lave distributions of income for his support and inamtenance. ${ }^{45}$ To undermine the government's strong estate and income tax position there, modification along the following lines might be attempted: income payable to $G$ for life in sucl amounts as the trustee (a bank or individual other than $G$ ) shall determine, ${ }^{46}$ remainder, including accumulated income, to $G$ 's children (Example 3 ). Will this broad delegation to the third-party trustee of the power to regulate the flow of trust mcome to $G$ prevent the adverse estate and income tax results associated with the limited discretionary trust (Exainple 2)?

1. Estate Tax Consequences. There is authority to support exclusion of the broad discretionary trust from $G$ 's gross estate. ${ }^{47}$ The rationale for this relaxed estate tax treatment of such a trust flows from the language of section 2036(a): the transferor "has retained for his life ... the possession or enjoyinent of, or the right to the income from, the property . . ."48 The legislative history of section 2036(a) suggests that the word "right" was inserted not to confine the application of the section to legal entitlement situations, but ratler to insure its application when such a right exists even though the trustee actually withholds distribution. ${ }^{49}$ Nevertheless, courts lave been inclined to rely on that phrase as a basis for a strict interpretation of paragraph (1) (relating to grantor's benefit) ${ }^{50}$ and of paragraph (2) (relating to gran-

45. See note 19 supra and accompanying text.

46. This would include the discretion to use for grantor's support. See text accompanymg notes 19-20 supra.

47. Lettice v. United States, 237 F. Supp. 123 (S.D. Cal. 1964); cf. Unitcd States v. Byrum, 408 U.S. 125 (1972) (settlor's retention of broad management powers did not necessarily subject inter vivos trust to the federal estate tax); Commissioner v. Irving Trust Co., 147 F.2d 946 (2d Cir. 1945) (trustee having absolute discretion to pay any excess principal to settlor, did not subject value of trusts mimus value of life estates to estate tax under 1926 Act). See also Rev. Rul. 76-368, 1976-2 C.B. 271.

48. I.R.C. $\$ 2036$ (a) (emphasis added).

49. H.R. REP. No. 708, 72 d Cong., Ist Sess. 46-47 (1932) ("where decedent had the right to the income, though he did not actually receive it").

50. See authorities cited in note 47 supra. 
tor's control over beneficial enjoyment). ${ }^{51}$

In a related context, the government has been successful in mcluding an outright lifetime gift im the transferor's gross estate when the required retention or "right" has been inplied from all of the facts and circumstances. ${ }^{52}$ Furthermore, grantor's retention of the discretionary power as trustee is inconsistent with exclusion of the unlimited discretionary trust from his gross estate..$^{53}$ Moreover, the government has recently revived the argument that the right of the grantor's creditors to reach trust assets subject to a trustee's broad discretionary power represents a form of grantor power to revoke under section 2038.54 These exceptions to the strict interpretation of section 2036(a) not only tend to penalize the grantor who has carelessly secured an "understanding" with the transferee (mcluding a third-party trustee) or who has made a mistake in the selection of trustee, but also forcefully expose the underlying policy question whether the transferor's "string" to the property is too great in all of the broad discretionary trusts situations. ${ }^{55}$

Section 2036(a) could be modified by Congress to require imclusion depending upon the identity of the trustee. For example, an "independent trustee" test of the type allowed under section 674(c) ${ }^{56} \mathrm{might}$ be imported into section 2036(a). The independent trustee test may be inappropriate in this settmg, however, because the trustee with the highest degree of independence (e.g., a bank) typically would believe that the trust instrument clearly authorized a distribution pattern that would give the grantor at least support and mamtenance payments from the trust. Even without an "understanding" with the grantor that would run afoul of the present rules, ${ }^{57}$ such a trustee might well mfer a "moral" obligation to supply the grantor with some minimal support from the trust income, at least when the grantor's other sources become inadequate. Given the broad discretion granted to the trustee, the remaindermen would not have any legal basis for asking a court to intervene for the purpose of regulating ordinary support distributions from

51. United States v. Byrum, 408 U.S. 125, 143 (1972).

52. Guynn v. United States, 437 F.2d 1148 (4th Cir. 1971); McNichol v. Commissioner, 265 F.2d 667 (3d Cir. 1959).

53. I.R.C. $\$ 2036(a)(2)$. "With respect to such a power, it is immaterial . . (ii) in what capacity the power was exercisable by the decedent . . ." Treas. Reg. $\$ 20.2036-1$ (b)(3) (1958).

54. Rev. Rul. 76-103, 1976-1 C.B. 293; see J. PESCHEL ๆ 4.02[C]n.20.

55. Lowndes, Some Doubts About the Use of Trusts to Avoid the Estate Tax, 47 MiNN. L. REv. 31, 48 (1962).

56. Generally, section 674(c) excepts from the general rule of section 674(a) trusts in which the power to distribute income and to pay out corpus is exercisable solely by a trustee who is not the grantor or a related or subordinated party subservient to the wishes of the grantor. See text accompanying notes 96-101 infra.

57. See cases cited in note $\mathbf{5 2}$ supra. 
the trust. The trustee's broad discretion, even when the trustee is a third-party trustee, suggests an estate tax result in Exainple 3 identical to that outlined for the limited discretionary trust (Exainple 2). ${ }^{58}$ At least the portion of the unlimited discretionary trust producing incone likely to be distributed for grantor's support might be included in the grantor's gross estate. A larger inclusion would not be foreclosed if the pattern of trust distributions during the grantor's lifetime suggested a more generous exercise by the trustee for the grantor's benefit; ${ }^{59}$ section 2036(a) should not be applied simply on the basis of a frozen set of factors present at the time of transfer. ${ }^{60}$ Even if a reworking of the statutory language in section 2036(a) is thought necessary, an equivalent estate tax result for both the limited discretionary and the broad discretionary trusts is likely to be appropriate and equitable in more situations than not.

2. Income Tax Consequences. Froin the grantor's viewpoint, the income tax picture for the broad discretionary trust (Exainple 3) ${ }^{61}$ is dismal. Without a trustee who has an adverse interest, the possibility of distribution of trust income to $G$ would be sufficient to tax him under section 677 (a) on the entire ordinary trust income. ${ }^{62}$ Since $G$ 's interest im trust income is not limited to the amount required for his support, the present language of section 677(a) does not accommodate the partial grantor trust treatment offered as a possible interpretation of the mcoine tax rules for the limited discretionary trust (Example 2) ${ }^{63}$

Correlating the income tax and estate tax results for the broad discretionary trust presents some problems. The recurring nature of income tax discourages use of the actual distribution pattern test suggested in the estate tax context ${ }^{64}$ because of admimistrative difficulties. Moreover, permitting the trustee to make periodic decisions that will directly affect the grantor's current income tax situation without preventimg the trustee from reconsidering the grantor's income tax status in later years seems too manipulative. This is not true with respect

58. See text accompanying notes 22-23, 33-34, \& 37-39 supra.

59. Inclusion in the gross estate of an amount less than the portion of the trust theoretically available for the grantor's support would'be justified if the trustee followed a policy of less generous distribution to the grantor.

60. Note that I.R.C. $\S 2036$ (a) presently applies to situations of required grantor benefit or control "for any period which does not in fact end before [the transferor's] death." Id.

61. See text accompanying note 46 supra.

62. I.R.C. $\$ 677$ (a) refers to trust income that "is" or "may be" distributed to the grantor in the discretion of a nonadverse party. With respect to corpus income, principally capital gains, see note 17 supra and accompanying text.

63. See text accompanying notes 26-27 supra.

64. See note 59 and text accompanying notes 59-60 supra. 
to the single application at the grantor's death of an actual distribution test based upon a now irreversible predeath pattern of distributions.

The prior discussion did not consider the identity of the trustee. Should the insulation of $G$ from income taxation under section 677(a) when the unlimited discretionary power is held by an adverse party (e.g., one of $G$ 's children, the remamdermen) be retained? ${ }^{65}$ The skepticism expressed above ${ }^{66}$ concerning the viability of trustee "adversity" based upon beneficial interest as a sufficient basis for grantor trust exemption applies equally to the broad discretionary trust situation-at least to the extent that a trustee will rarely resist a request for support payments. However, it would be reasonable to expect that the adverseparty trustee would inore frequently resist nonsupport distributions, particularly large distributions for frivolous or marginal purposes, than would an imdependent or nonadverse trustee. If such a distinction were accepted, the application of section 677(a) would be virtually identical for limited and for broad discretionary trusts: grantor's income tax exposure under section 677(a) would be limited to the portion of the trust available for his support needs.

3. Gift Tax Consequences. The gift tax analysis of the broad discretionary trust (Example 3 ) is complicated by an erratic quality in the government's approach. Under the regulations the trust transfer will be considered complete so long as the broad discretionary power is vested in a third party, even though the grantor may benefit from the exercise of the trustee's discretion. ${ }^{67}$ On the other hand, some adverse decisions on the gift tax issue prompted the government to rule that the possibility of grantor benefit made the transfer incomplete even though the amount of grantor benefit was not determimable because of the absence of an ascertamable standard limitimg the exercise of the trustee's power. ${ }^{68}$

65. "Under section 677 the grantor is treated as the owner of a portion of a trust if he has retained any interest which might, without the approval or consent of an adverse party, enable him to have the income from that portion, distributed to him at some time . . ."Treas. Reg. $\S 1.677(\mathrm{a})-1$ (c) (1960).

66. See note 44 supra and accompanying text and text preceding note 40 supra.

67. "As to any property, or part thereof or interest therein, of which the donor has so parted with dominion and control as to leave in him no power to change its disposition, whether for his own benefit or for the benefit of another, the gift is complete." Treas. Reg. $\$ 25.2511-2$ (b) (1958).

68. Rev. Rul. 62-13, 1962-1 C.B. 181. Cases prompting the ruling are discussed therein. However, in Rev. Rul. 77-378, 1977-2 C.B. 24, the earher ruling was clarified "to remove any implication that an entirely voluntary power held by a trustee to distribute all of the trust's assets to the grantor as sufficient to render a gift incomplete either in whole or in part." Id. The net result may be to limit incompleteness to situations where the grantor's creditors have rights. See text accompanying note 69 infra. 
More recently, the government concluded that a gift was incomplete by resuscitating an old argument that the rights of the grantor's creditors to reach the assets of the broad discretionary trust amounted to an indirect grantor power to revoke; the grantor could incur debts that, to the extent not repaid by the grantor, would support creditor access to the trust assets under local law. ${ }^{69}$ This latest government position on the gift tax problem clearly imdicates that the complementary effect of the incomplete gift for gift tax purposes is inclusion in the gross estate under section $2038 .^{70}$ This "backdoor" search by the government for a solution to the estate tax treatment of the unlimited discretionary trust is unfortunate not only because different estate tax treatment for identical trusts will result froin variations in local law but also because the operative effect of the disadvantageous local law is questionable. ${ }^{71}$ Far preferable would be a direct government attack on the questionable estate tax authorities granting an exemption for the broad discretionary trust, ${ }^{72}$ or, if necessary, legislative rehef in the form of extending the broad "is," or "inay be" distributed to the grantor approach of section 677(a) to section 2036(a)(1).

\section{Indirect Grantor Benefit Trusts.}

A prospective grantor may be prepared to forego possible direct trust income distributions to himself, not only to improve the tax picture but also because he is confident regarding the irrevocable release of "excess" assets. Yet, he may wish to retain a limited string to the property, illustrated by the following trust (Exainple 4): income payable to $G$ 's children in such amounts as the trustee deems necessary for their support and maintenance, remainder distributable to $G$ s children when they attain certain ages. In determining the completeness of this trust for federal tax purposes, the indirect benefit to $G$ in the form of satisfying a legal obligation to support his minor children cannot be disregarded. In general, the same factors considered with respect to direct grantor benefit trusts-the scope of the beneficiary's rights, the trustee's discretion, and the identity of the trustee-will produce the same federal tax result for this type of indirect grantor benefit trust. ${ }^{73}$

The most important exception is section 677(b), which limits the

69. Rev. Rul. 76-103, 1976-1 C.B. 293.

70. "II]f the grantor dies before the gift becomes complete, . . . the trust corpus will be includible in the grantor's gross estate . . . under section 2038 . . . because of the grantor's retained power to, in effect, terminate the trust by relegating the grantor's creditors to the entire property of the trust." $I d$. at 294.

71. See generally 4 A. ScoTT, supra note 21, \$330.12.

72. See note 55 supra and accompanying text.

73. See text accompanying notes $16-44$ supra. 
amount of income included in the grantor's income to the amounts of trust income actually "applied or distributed" to satisfy the grantor's legal obligation of support. This retreat from the broad access test of section $677(\mathrm{a})^{74}$ is quite advantageous to the grantor who creates a trust for the benefit of his children without any express reference to their support and maintenance. Although actual distributions for their support and maintenance will be common, the trust will be excluded from $G$ 's gross estate ${ }^{75}$ on the theory that neither he nor the beneficiaries have a right to compel distributions for such purposes and the adverse imcome tax result under section 677(b) is himited to actual use of trust income for such purposes.

\section{E. Other Grantor Benefit Trusts.}

The preceding examples of trusts with direct or imdirect grantor benefit that jeopardize the grantor's estate and income tax goals have been confined to trusts in which the grantor's access is limited to the income interest. Such an approach isolates the basic features of the existing tax rules relating to the general focus of this Article: trustee identity and fiduciary standards. Needless to say, the variety of grantor benefit trusts has only been sampled. Beyond the obvious variation of trusts giving the grantor access to trust principal as well as income, certain specialized types of trusts, such as short-term trusts with a reversionary interest in the grantor, ${ }^{76}$ and property transfers subject either to outstanding debts (nnortgages) or to imdebtedness created by the gratuitous transfers (the gift tax) ${ }^{77}$ raise problems that need not be explored here. The income-only grantor benefit trusts adequately illustrate the broader policy issues considered in this Article. ${ }^{78}$

\section{Grantor Control}

\section{A. Direct Power to Control Beneficial Enjoyment.}

A grantor who lacks knowledge of the basic tax rules in this area should not be surprised to learn that direct and even indirect retained benefit from an irrevocable inter vivos trust will typically jeopardize realization of the income and estate tax goals commonly attributed to

74. The various technical limitations of section $677(\mathrm{~b})$ are discussed in Treas. Reg. $\$ 1.677(\mathrm{~b})-1$ (1960).

75. See text accompanying notes 47-60 supra.

76. See generally J. Peschel T] 4.08 .

77. Id. II 4.06; Fuller, Transferring Liabilities: Tax Effects, 12 GA. L. REv. 33 (1977).

78. See text preceding and accompanying notes $142-43$ infra. The classic revocable trust that enables the grantor without limitation to revest the trust property in himself was not explored because such a trust achieves no income or estate tax advantages. See generally J. PESCHEL ch. 6. 
such trusts. More understandable would be the grantor's surprise upon discovery that trust forms in which the grantor and, in soine cases, third-party trustee have only the power to control beneficial enjoyment in third party beneficiaries will also jeopardize the estate and income tax goals, even when the grantor lacks any access to the trust income or principal. Indeed, estate planning professionals may overlook or underestimate the continuing risk of the control situations.

1. Grantor as Trustee. Suppose that grantor $G$ declared an irrevocable trust of certain property: income payable to $A$ in such amounts as the trustee, $G$, shall determme, remainder, including any accumulated income, payable to $B$ upon the death of $A$ (Example 5) ${ }^{79}$

(a) Estate tax consequences. The broad power of $G$, in his role as trustee,${ }^{80}$ to withhold income from $A$ and to cause distribution of that income to $B$ will require the full value of the trust to be included in $G$ 's gross estate upon his death under section 2036(a)(2). ${ }^{81}$ The tax result here is properly the same as that when the grantor has retained a beneficial interest. ${ }^{82}$ Similar to the situation in which the grantor has retained a beneficial interest for life, ${ }^{83}$ this inter vivos transfer assumes a testamentary nature: the grantor retains for life a significant aspect of the property, the power to control its enjoyment. Only upon death is that power relinquisled. Inclusion in the gross estate is thus wholly justified. ${ }^{84}$

(b) Income tax consequences. Ordmary income from the trust will be taxable to $G$ under section 674(a) whether or not the income is actually distributed to $A$ or withheld for future distribution to $B .^{85}$ Continued taxation of the ordinary income to $G$ depends only in a

79. If $A$ were $G$ 's adult child, there is very hittle risk of adverse estate or incoine tax consequences on the theory of retained grantor benefit. However, a grantor has been subjected to income tax when he inadvertently becaine the actual debtor for certain expenditures (e.g., college education) incurred for the benefit of his child. Morrill v. United States, 228 F. Supp. 734 (S.D. Me. 1964); $f f$. Wyche v. United States, 36 A.F.T.R.2d 75-5816 (Ct. Cl. Tr. Div. 1974) (incoine from short-term trusts created by taxpayer for his children's private school education not includible in his income).

80. Under I.R.C. $\$ 2036(a)(2)$, the capacity in which the grantor holds the power is immaterial. Treas. Reg. $\$ 20.2036-1(b)(3)$ (1958).

81. Full inclusion of the trust assets, not merely the value of $A$ 's income interest, is required by section 2036(a)(2). Treas. Reg. $\$ 20.2036-1$ (a) (1958). This is the case even though the overlapping section 2038 would include only the value of the interest subject to modification. Treas. Reg. $\S 20.2038-1$ (a) (1958).

82. See text accompanying notes 11-12 supra.

83. See text following note 9 supra.

84. See Porter v. Commissioner, 288 U.S. 436 (1933).

85. The capital gams and other income allocable to principal will not be taxable to $G$, be- 
backward fashion on the broad language of section 674(a), which on its face resembles the general test for inclusion in the gross estate under either section 2036(a)(2) ${ }^{86}$ or section 2038(a). ${ }^{87}$ Section 674(a) operates as a broad grantor trust rule applicable where "the beneficial enjoyinent of the corpus or the income therefrom is subject to a power of disposition," ${ }^{88}$ unless one of the detailed exceptions found in sections 674(b)-(d) is applicable. In Exainple 5, neither subsection (c) or (d) supplies the exemption because the grantor cannot be a trustee holding the powers described in those provisions. ${ }^{89}$ Of the exceptions contained im subsection (b), only two are sufficiently relevant to require comment. Paragraph (7) is not applicable because the power to withhold exists beyond the time when the beneficiary has attained the age of twentyone. ${ }^{90}$ Paragraph (6) requires that the withheld income must ultimately be payable either to the beneficiary from whom withheld, his estate, or appointees or to the current income beneficiaries in shares irrevocably specified in the trust instrument. ${ }^{91}$

(c) Gift tax consequences. Retention by the grantor of the power, not subject to an ascertainable standard, to shift the income interest from $A$ to $B$ will cause the gift of the income interest to be incomplete for gift tax purposes. ${ }^{92}$

2. Third-Party Trustee. The principal avenue of estate and income tax relief for $G$ in Example 5 lies in the identity of the trustee or the scope of the trustee's discretionary power to withhold income. Suppose that $G$ designates one of the following as trustee: (1) $C$, his

cause he is not deemed to be the owner of that portion of the trust. Treas. Reg. $\S 1.671-3(b)(1)$ (1960).

86. Inclusion is predicated upon the power to "designate the persons who shall possess or enjoy the property or the income therefrom." I.R.C. §2036(a)(2).

87. Inclusion is predicated upon the power to "alter, amend, revoke, or terminate . . . ." I.R.C. $\S 2038(a)(1)$, (2).

88. I.R.C. \& 674(a).

89. Nor can the grantor's spouse who is living with him be a trustee under section 674(d), while such spouse could be one of the trustees under the independent trustee exception. I.R.C. $\S 674$ (c). Of course, the unlimited discretionary power in Example 5 also violates the "reasonably definite external standard" of section 674(d).

90. This exception does permit payınent of the withheld income to a person other than the minor beneficiary, his estate, or appointees. Treas. Reg. $\S 1.674(b)-1(b)(7)$ (1960).

91. The language of Paragraph (6) permits alternative takers of the accumulated income (other than the grantor or his estate) in the limited circumstances where the alternate gift takes effect on the failure of the primary beneficiary to survive to a date of distribution "which could reasonably have been expected to occur within the beneficiary's lifetime." I.R.C. $§ 674(b)(6)$. The regulations make clear that this exception would not protect the grantor in Exanple 5. Treas. Reg. $\S 1.674(b)-1(b)(6)(c)(1960)$.

92. Treas. Reg. \& 25.2511-2(c) (1958). 
brother; (2) $X$ Bank; or (3) $B$, the remainderman.

(a) Estate tax consequences. Any one of these third-party trustees would prevent inclusion in $G$ s gross estate, since both sections 2036 (a)(2) and 2038 require that the grantor "alone or in conjunction with any person" have the proscribed powers. Apparently, a "friendly" trustee, particularly $C$, a close relative without an interest in the trust, will satisfy the statutory requirements. So long as the trustee has not coinpletely delegated the actual responsibilities to the grantor, it will be very difficult for the government to invoke its regulatory warning that an "interest or right is treated as having been retained or reserved if at the time of the transfer there was an understanding, express or implied, that the interest or right would later be conferred."93 It is to be hoped that even the "friendly" trustee takes seriously his fiduciary obligations and the possible surcharge claim arising im the complete capitulation situation. Moreover, occasional deference to the grantor's "suggestions" when the disbursement is well within broad fiduciary standards should not constitute the "implied understanding" referred to in the. regulations. ${ }^{94}$ The appointment of $X$ Bank (unless friendly in the extreine terms suggested above) and $B$ (a beneficiary with an adverse interest in the exercise of the discretionary power) should not raise any serious problems regarding exclusion of the trust from $G$ 's gross estate. ${ }^{95}$

(b) Income tax consequences. For mcome tax purposes, each of the proposed candidates for trustee must be tested agamst a more sophisiticated and detailed statutory scheme-section 674 . So long as the scope of the power in Example 5 remained constant, appoimtment of $C$ as trustee would not prevent taxation to $G$ on the ordinary trust income. Under section 674 (c), such a broad discretionary power over income must be held "by a trustee or trustees, none of whom is the

93. Treas. Reg. \& 20.2036-1(a) (1958) (final sentence).

94. See id. In Estate of Goodwyn, 32 T.C.M. (CCH) 740 (1973), the government appeared to have the extreme case of trustee delegation to the grantor. Nevertheless, no "right" in the grantor as required by the Supreme Court's interpretation of I.R.C. $\S 2036(\mathrm{a})$ in United States v. Byrum, 408 U.S. 125 (1972), was found to exist. Whether the result in Goodwyn was changed by the revised anti-Byrum provision, Revenue Act of 1978, Pub. L. No. 95-600, \& 702(i), 92 Stat. 2931 (enacting a new section 2036(b)), depends upon the elastic language "retention of the right to vote (directly or indirectly) shares of stock of a controlled corporation. . . " Id. (emphasis added). Commentators have expressed serious doubts about the correctness of the Goodwyn decision. See Gaubatz, The Nontaxation of Nontestamentary Acts: Will Byrum Survive the Tax Reform Act of 1976?, 27 CASE W. Res. L. Rev. 623, 641-42 (1977); Pedrick 729.

95. However, regarding B's tax problems, see Peschel, Family Members as Trustees: Part II-Tax Problems for the Trustee/Beneficiary, 2 Rev. TAx. Individuals 351 (1978). 
grantor, and no more than half of whom are related or subordinate parties who are subservient to the wishes of the grantor."96 Unfortunately, the statutory list of related or subordmate parties includes the grantor's brother. ${ }^{97}$ Membership on the prescribed list does not automatically bar classification of such persons as independent trustees because section 674(c) imposes the additional requirement that such parties be "subservient to the wishes of the grantor." However, section 672(c) "presumes" such subservience in the case of a related or subordinate party unless the contrary is shown by the preponderance of evidence. This escape valve will hardly be a practical provision for the estate planner in the absence of a clear pattern of family estrangement.

$X$ Bank should qualify ${ }^{98}$ as a trustee whose possession of the power will ineet the requirements of section 674(c), thus preventing the trust income froin being taxed to the grantor. Even if $X$ Bank and $C$ were to act as co-trustees, the grantor would not be subject to income tax under section 674(c). ${ }^{99}$ Because $B$ has a self interest as remamderman to accumulate the trust mcome, section 674(a) does rot apply. ${ }^{100}$ Even if $B$ were related to $G$ in a way described in section 672(c), the exemption supplied by section 674(c) would continue because a "related or subordinate party" means any nonadverse party who is on the statutory checklist. ${ }^{101}$

The appointment of $B$, an adverse party, achieves income tax protection for $G$ at the possible cost of income taxation to $B$ under section 678(a). However, section 678(a) speaks of a power exercisable solely by a person other than the grantor "to vest the corpus or the mcome there-

96. 1.R.C. $\S 674(\mathrm{c})$.

97. Id. $\S 672(\mathrm{c})$. The statutory checklist is specific and generally comprehensive, so estate planners seeking to qualify under the "independent trustee" exception should always consult it to insure compliance. Presumably, an independent attorney or accountant who is doing standard professional work would not be an employee for these purposes. $C f$. Rev. Rul. 66-160, 1966-1 C.B. 164 (corporate director not an "employce"). See also Westfall, Trust Grantors and Section 674: Adventures in Income Tax Avoidance, 60 CoLUM. L. REv. 326, 340 (1960). This author criticizes both sections 674 (c) and (d), for "a remarkably naive set of assumptions with respect to the effective exercise of control by a grantor." $/ d .339$.

98. However, under section 672(c)(2), a corporation in which the stockholdings of the grantor and trust are significant from the viewpoint of voting control is a related or subordinate party.

99. I.R.C. $\S 674(\mathrm{c})$. Clearly, the more-than-one-half statutory exception is based upon the normal rule that unanimity is required in the case of multiple trnstees. $3 \mathrm{~A}$. ScoTT, supra note 21 , $\S 194$. Therefore, the draftsman should not include modifications that exclude the independent trustee from voting on the exercise of the discretionary power. Moreover, broad provisions for removal of the trustee by the grantor should be avoided. Treas. Reg. $\S 1.674$ (c)-2(a) (1960).

100. In Example 5, $B$ 's power over the trust income should qualify despite the warning in the regulations that a remainderman's power over income "inay be" one exercisable by a nonadverse party. Treas. Reg. $§ 1.672$ (a)-l(d) (1960). In the regulations' exainple, the remainderman could not benefit himself by the exercise of the power over incone.

101. I.R.C. \& 672(c). 
from in himself." 102 It is not clear that section 678(a) apphies when the nongrantor (in Example 5, the remainderman) can enjoy the income over which he has a power only in the future (im Example 5, at $A$ 's death). ${ }^{103}$ Obviously, the principal situation contemplated by section 678 (a) was the immediate power to withdraw trust mcome. ${ }^{104}$

(c) Gift tax consequences. For gift tax purposes, the appointment of any of the three parties would make the transfer complete, ${ }^{105}$ even though an unlimited power to accumulate trust income is held by the third-party trustee. In contrast, if $G$ were the trustee, the value of the interest subject to change through exercise of the unlimited power (that is, the actuarial value of $A$ 's income interest) would be an incomplete transfer. ${ }^{106}$ Unlike the situation under the estate tax rules regarding joimt powers, ${ }^{107}$ the entire value of the property would be a completed gift if $G$ shared the discretionary power in Example 5 with $B$, a party with a "substantial adverse imterest." 108 Otherwise, the gift tax rules $\mathrm{m}$ this area of grantor control generally complenent those applicable for estate tax purposes. ${ }^{109}$

\section{B. Limited Discretionary Power.}

To what extent can $G$ improve his estate and income tax picture by modification of the discretionary power in Exanple 5 rather than by appointment of a third-party trustee? Suppose that $G$ is authorized by the trust instrument to distribute such amounts of trust income as he, as trustee, deems necessary for $A$ 's support and maintenance, with any remaining income to be added to corpus for distribution to $B$ at the death of $A$. Even though the grantor held the limited power to affect beneficial enjoyınent until his death, neither section 2036(a)(2) nor section 2038 would cause the value of the trust assets to be included im his gross estate. ${ }^{110}$ The cost of this estate exemption is a fully completed

102. Id. $\S 678(\mathrm{a})(1)$.

103. Cf. I.R.C. $\S 677(a)(2)$ (which taxes the grantor currently even if actual enjoyment is postponed).

104. See, e.g., Rev. Rul. 67-241, 1967-2 C.B. 225 (limited power to request trust corpus in any year).

105. Treas. Reg. $\S \S 25.2511-2$ (b), (c), \& (f) (1958).

106. Treas. Reg. $\$ 25.2511-2$ (b) (1958). See text accompanying note 92 supra.

107. See text preceding note 93 supra.

108. Treas. Reg. $\$ 25.2511-2$ (e) (1958).

109. The gift is incomplete only to the extent of the actuarial value of the interest subject to modification, see text accompanying note $106 \mathrm{supra}$, while the entire value of the property, the value of which is subject to grantor control, is included in the gross estate under section 2036(a)(2), see note 81 supra.

110. An early case reaching this result is Jennings v. Smith, 161 F.2d 74 (2d Cir. 1947). See 
transfer for gift tax purposes. ${ }^{11}$

For income tax purposes, further modification of the trust would be required to prevent the application of section 674(a). Under section 674(b)(6)(A), the withheld income would have to be ultimately payable to $A$, lis estate, or appointees (if $A$ were given a power of appointment over the accumulated income). ${ }^{12}$ Under a limited exception spelled out in section $674(\mathrm{~b})(6)$, an alternative gift of the accumulated income could be specified in the trust instrument, provided that the donee is not the grantor or his estate and that sucl gift takes effect only upon the failure of the primary beneficiary $(A)$ to survive to a date of distribution "whicl could reasonably have been expected to occur within the beneficiary's lifetime." 113 The only remedy for $G$ which is consistent witl the original Example 5 pattern of distribution of accuinulated incoine to $B$ at $A$ 's death is the coinbination under section 674 (d) of a power over income limited by a "reasonably definite external standard" whicl is held by a trustee or trustees, "none of wliom is the grantor or spouse living with the grantor."114

\section{Trusts for Minors.}

A typical individual considering an inter vivos gift to his mimor descendants will want to retain control of the beneficial enjoyment of property when outright possession by the donee is to be withheld. Indeed, a form of trust (or other custodial device) ${ }^{15}$ may well be justified solely on the grounds that an outright bequest is unsuitable for a person so inexperienced in liandling substantial amounts of property and that the archaic guardianship rules in many states discourage a representative form of transfer. ${ }^{116}$ Suppose that $G$ declared an irrevocable trust of

generally R. STEPHENS $\{4.10[5]$. The weak statutory basis for this exception is noted in Pedrick 731 .

111. Treas. Reg. \& 25.2511-2(c) (1958).

112. The statute only requires that the power of appointment be one that does not exclude from the appointee group any person other than the beneficiary, his estate, his creditors, or the creditors of his estate. Thus, $A$ could be given a special power over the accumulated income without causing it to be included in his gross estate under section 2041(a), provided the accumulated income could not be payable to any of the four categories excludable under section $674(\mathrm{~b})(6)(\mathrm{A})$.

113. 1.R.C. \& 674(b)(6). The other exccption, section 674(b)(6)(B), would not be applicable in a modified Example 5 unless other "current income" beneficiaries were added. One writer has suggested that the entire exception, section $674(\mathrm{~b})(6)$, is too broad and should be repealed. Westfall, supra note 97 , at 345 .

114. I.R.C. \& 674(d).

115. An example would be registration of shares under the Uniform Gifts to Minors Act, which can be thought of as a simple form of statutory trust. UNIFORM GIFTS TO MINORS ACT $\S \S 2,4(\mathrm{~g})$ (1966 version).

116. J. Dukeminier \& S. Johanson, Family Wealth Transactions 86-91 (2d ed. 1978). 
property, income, and corpus payable to $A$ ( $G$ 's minor son) in such amounts as the trustee $(G)$ shall determime, corpus and any accumulated income payable to $A$ when he attains age twenty-one. No portion of the trust income or principal can be used to satisfy $G$ s legal obligation to support $A$ (Example 6). ${ }^{17}$

If $G$ died before the trust terminated, the entire value of the trust property would be included in his gross estate under either section 2036(a)(2) or section 2038. ${ }^{118}$ This is so despite the fact that $G$ 's power over income and primcipal does not involve the ability to choose among beneficiaries, but only an ability to choose the time or maimer of enjoyment of the property by $A{ }^{119}$ Simce $A$ 's death before attaming age twenty-one is statistically improbable, the choice between present enjoyment by $A$ or future benefit for $A$ 's heirs, distributees, appointees, or an alternative designated taker can be properly disregarded as a power to determine the identity of the beneficiary. The government takes the inconsistent position that this trust transfer is complete for gift tax purposes. ${ }^{120}$

$G$ s position for income tax purposes is protected by section 674(b)(7) even when the grantor or a nonadverse party holds the power to withhold income during the period before the beneficiary attains age twenty-one. ${ }^{121}$ In the case of a single beneficiary trust the requirements of section 674(b)(5) are met, since $G$ 's power over trust primcipal necessarily involves a charge against the beneficiary's proportionate share of

117. Without the latter restriction, $G$ 's income and estate tax problems would arise in part from the indirect retained benefit in the form of satisfying his support obhigation. See text accompanying notes 66-68 supra. The restriction is included here, not on the ground that it is necessarily desirable, but only for purposes of confining the present discussion to $G$ 's tax probleins fiowing from retained control rather than benefit. The desire for fiexibility in the event that $G$ 's personal assets are inadequate to meet $A$ 's needs, or as a funding device in anticipation of $G$ 's death (whether or not the legal obligation survives $G$ s death) may justify allowing the use of trust income or principal for such a purpose. To minimize tax problems, $G$ may be encouraged to appoint a third party as trustee.

118. See, e.g., Lober v. United States, 346 U.S. 335 (1953). The same result is reached if $G$ was custodian of property under the Uniform Gifts to Minors Act. Rev. Rul. 70-348, 1970-2 C.B. 193. Relief from the adverse estate tax result requires appointment of a third-party trustee(s) in order to take advantage of the generous feature of sections 2036(a)(2) and 2038, which state that the proscribed power must be held by the grantor alone or in conjunction with any person. With respect to sham third-party trustee appointunents, see note 94 supra.

119. Suppose that $G$, as trustee, has only a power over trust incoine. An argument has been made that section 2036(a)(2) does not apply because the power to designate the "person" who will enjoy the property is not involved, but the power to determine time and manner is a power to alter or amend for purposes of section 2038(a). Under the latter section, only the value of the interest subject to such power (i.e., income until $A$ attained age) is included in the gross estate. See $\mathrm{R}$. STEPHENS ๆ 4.109[9].

120. Treas. Reg. \& 25.2511-2(d) (1958).

121. The same exception applies to a power over income when the current income beneficiary is under any form of legal disability. 
trust property.

Suppose that $G$ feels that age twenty-one is still too early for an outright distribution to $A$ and consequently provides for further delay of distribution of accumulated incoine on corpus until $A$ attams an older age, such as thirty or thirty-five. Neither the basic estate nor gift tax consequences described above for the true minor's trust (Example 6 ) turn on ternination of the trust at age twenty-one. In contrast, the age twenty-one termination date for the incoine power under section 674(b)(7) shifts the income tax focus to another exception-section 674(b)(6)-which authorizes a "temporary" withholding of income from the beneficiary provided that the accumulated income must "ultimately be payable-(A) to the beneficiary from whom . . . withheld, to his estate or to his appointees" under a power of appointment of a type specified. ${ }^{122}$ A designated alternative taker (other than the grantor or his estate) can be given the accumulated incoine if the primary beneficiary "does not survive a date of distribution which could reasonably have been expected to occur within the beneficiary's hfetime . . . ."123 Also, the grantor continues to be protected with respect to the power over the corpus under section $674(\mathrm{~b})(5)$.

\section{Administrative Powers.}

The grantor's estate and income tax picture improves appreciably as the scope of trustee power over beneficial enjoyment, when not combined with potential grantor benefit, decreases. ${ }^{124}$ Indeed, careful selection of a third-party trustee is consistent with favorable tax results even where the power over beneficial enjoyinent is quite broad. ${ }^{125}$ Suppose that $G$ created a trust declaring himself trustee, all current income payable to $A$ for hife, remainder to $B$ (Example 7). One might expect that the elimination of any direct control of beneficial enjoyment would assure favorable estate and income tax consequences to $G$. However, the trustee's standard administrative powers, such as selection of investments, capacity to vote corporate shares, and incoine-primcipal allocations, have, in certain circumstances, been regarded as a source of indirect control over beneficial enjoyment. For example, $G$ could favor $A$ over $B$ by investing in high-yield bonds rather than a more speculative long term growth stock.

122. I.R.C. $\$ 674(b)(6)$; see note 112 supra.

123. I.R.C. $\$ 674($ b)(6). A similar but broader rule applies under section $674(\mathrm{~b})(7)$ (relating to withlolding until age 21); the income accumulated during the minority period can be added to corpus distributable to a third party. Treas. Reg. $\S 1.674(b)-1(b)(7)(1960)$.

124. See text preceding note 110 supra.

125. See text following note 92 supra and accompanying notes 93-96 supra. 
For estate tax purposes, the broad language of sections 2036(a)(2) and 2038 would not foreclose a government argument that the grantor's strings to the property are sufficient to cause inclusion in his gross estate. With one inajor exception, the government's campaign for a broad interpretation of the estate tax rules in the administrative power area peaked a number of years ago when the First Circuit held that a coinbination of administrative powers shared by the grantor with a third-party trustee was subjcct to such loose standards that they represented an indirect control of beneficial enjoyment. ${ }^{126}$ After the estate planning bar absorbed the initial shock of this decision, a steady recovery occurred, initially through cases ${ }^{127}$ that found some basis for distinguishing the adverse decision, and finally through a review of the matter by the same court of appeals that resulted in an overruling of the earher decision. ${ }^{128}$ Today, the prevailing view is that even the grantor can retain as a trustee standard administrative powers (other than the right to vote corporate shares, as discussed below) without serious risk of inclusion in his gross estate. ${ }^{129}$

The legal rationale for this restrictive interpretation of the estate tax sections is the traditional view that a trustee cannot exercise such administrative powers in an arbitrary or bad faith fashion even though the trust language (or the state law) clearly conteinplates broad discretion. In its reconsideration of the State Street Trust rule, the First Circuit conceded that a state court could not be excluded in the ordinary administrative power situation from reviewing extreme trustee actions. ${ }^{130}$ Some commentators have argued also that a trustee (imcluding a grantor) would not typically exercise the administrative powers in a way that consciously manipulates the competing interests of trust beneficiaries. ${ }^{131}$ Whether the grantor would lose his estate tax exemption by reserving some administrative powers in a nonfiduciary capacity is, of course, technically left open by the favorable line of authorities. Some have suggested that an "iniphed fiduciary obligation" may still regulate the grantor who retains such powers when he is not at least a cotrustee. ${ }^{132}$

With respect to a power to vote corporate shares, a grantor who had retained such a power was able to convince a majority of the

126. State St. Trust Co. v. United States, 263 F.2d 635 (Ist Cir. 1959).

127. See cases cited in R. Stephens If 4.08[6] [a] n.53.

128. Old Colony Trust Co. v. United States, 423 F.2d 601 (1st Cir. 1970).

129. See, e.g., R. Stephens \ 4.08[6][a]. This conclusion is echoed in Pedrick 725-26, but the author there advocates reconsideration by the Supreme Court.

130. Old Colony Trust Co. v. United States, 423 F.2d 601, 603 (1st Cir. 1970).

131. See, e.g., Gaubatz, supra note 94, at 636-37. But see Pedrick 725.

132. R. STEPHENS \{ 4.10[4][c]. 
Supreme Court in United States v. Byrum ${ }^{133}$ that corporate fiduciary obligations prevented him from voting a majority interest in a corporation so as to manipulate the dividend policies and the appointment of executives and directors. Consequently, the grantor did not have the "right" to possession or enjoyinent as required by section 2036(a)(1), or the control of such right as required by section 2036(a)(2). Congressional dissatisfaction with the Byrum decision was initially reflected in a sweeping amendment to section 2036(a)(1) that "retention of voting rights in retained [sic] stock shall be considered to be a retention of the enjoyment of such stock." "134 Criticism of the scope of the anti-Byrum rule prompted a substantial rewriting now reflected in a new section 2036(b), ${ }^{135}$ which confines the mclusion generally to cases involving controlled corporations. ${ }^{136}$

With respect to the income tax treatinent of administrative powers, Congress long ago responded by enacting section 675..$^{137}$ Aside froin certain restrictions against trust administration designed to benefit the grantor in a way not usually needed or desired in the standard trust, ${ }^{138}$ section 675(4) does provide for grantor trust treatunent of some standard powers of admimistration. The adverse result is fairly easily avoided because the power to vote corporate shares or to select trust investment will be a problem only if the power is exercisable in nonfiduciary capacity' ${ }^{139}$ and "the holdings of the grantor and trust are significant from the viewpoint of voting control." 140

For gift tax purposes, little direct attention has been paid to the problem of administrative powers, although indications are that the governnient position would be that the transfer is still complete even though the grantor retains the powers. ${ }^{141}$

133. 408 U.S. 125 (1972).

134. Tax Reform Act of 1976, Pub. L. No. 94-455, § 2009(a), 90 Stat. 1893. "Retained" should be "transferred."

135. Revenue Act of 1978, Pub. L. No. 95-600, § 702(i), 92 Stat. 2931.

136. Exploration of the details of the revised anti-Byrum rule will not be undertaken here because they are not central to the principal subject of this Article. The amount of literature on Byrum is substantial. For two views expressed prior to the 1978 revision, see Pedrick and Gaubatz, supra note 94.

137. A broad exemption for an income/principal allocation power was also included in section $674(\mathrm{~b})(8)$, which permits even a grantor to hold such power.

138. I.R.C. § 675(I) (bargains transactions involvimg trust property); I.R.C. § 675(2),;(3)(borrowing from the trust); I.R.C. $\S 675(4)$ (C) (substitution of new trust assets).

139. Compare the anti-Byrum rule in which inclusion in the gross estate results whether or not the power to vote is held in a fiduciary capacity. S. REP. No. 745, 95th Cong., $2 \mathrm{~d}$ Sess. 22 (1978) (Part B).

140. For a criticism of section 675, see Pedrick 731 n.130 ("Some of us think it overly generous").

141. J. Peschel, T 5.05[H]. 


\section{Evaluation of Existing Law}

The lengthy analysis of the federal tax treatment of typical irrevocable inter vivos trusts sets the stage for a response to the central question raised in the introduction to this Article: How do the existing income, estate, and gift tax rules fare when tested by various policy considerations? The use of the plural emphasizes that it is not appropriate to reduce the inquiry to a determination whether existing law adequately protects agamst "tax avoidance." This rubric either constitutes a question-begging label for the basic problem or improperly excludes important considerations affecting the constructicn of a balanced tax systein in this area. To be sure, the dominant question is the extent to which the grantor of an irrevocable inter vivos trust should be permitted the estate and income tax advantages normally associated with such transfers when he has retamed some degree of benefit or control. Final resolution, however, must take into account other public policy factors, some of which reflect the goals or legitimate interests of grantors, trustees, and other parties directly mvolved in the trust.

Since more than one federal tax is involved, the estate plaimer and his client are entitled to operate within a legal context that does not unnecessarily or incoherently establish different rules for the same basic transaction. Moreover, the rules should be formulated and administered with the maximum feasible degree of certainty. Not only are the iminediate parties in interest justified im expecting a system that fosters stable estate planning at the planning and drafting stages, ${ }^{142}$ but the public interest supports a system that mimimizes the cost, in terms of private and public resources, of controversy after the event. Even at the drafting stage, the rules should not be so complex and uncertain as to entrap the unwary professional who is making a bona fide effort to coinply with them.

Factors external to the specific tax context should be given appropriate weight. Thus, the content and operation of nontax fiduciary law should not be disregarded and normal assumptions regarding human behavior, instincts, and goals should prevail. A degree of tolerance for "tax avoidance" by a few greedy grantors might be preferred to the creation of a system that will operate as a straightjacket for the majority, whose inclinations may not be so base. On the other hand, a large percentage of Americans will neither be interested in nor be able to afford a "complex" estate plan, which includes irrevocable inter vivos

142. Professor Westfall worried that too much weight was being given to this factor when Congress drafted section 674 (relating to power to control beneficial enjoyment in the income tax setting). See Westfall, supra note 97, at 328. 
trusts. Consequently, the rules goveruing such transfers should not become so relaxed that the wealthy few can achieve substantial tax savings not readily available to the majority. ${ }^{143}$

On balance, there is a strong argument that the present federal tax rules governing irrevocable inter vivos trusts reflect an inadequate response to these various policy considerations. The problems with the existing systein are so diverse that both sides (that is, the tough tax reformer and the person more sympathetic to the interests of the parties directly affected) have ample ground to complain. Since each side can isolate specific problems that indicate that the rules are either too generous or too tough, it is difficult for anyone to stake out a neutral position without making, or at least expressing, an underlymg assumption. To increase the utility of this Article, two alternative packages for revisions in the present system will be described, one of which makes them tougher and the other, more relaxed. It is believed that inany people would agree that the present rules are unsatisfactory but that reasonable people will disagree over which direction reform should take.

\section{A. Tougher Rules.}

A reader who assigns a high priority to the construction of barriers to tax avoidance among high-income and wealthy mdividuals will be attracted to this position. Since the irrevocable inter vivos trust is widely used by this group, the present rules would seem to be a ready target for revision. A responsible tough tax reformer will not openly advocate uncertainty or excessive complexity in the rules, but he may feel less syinpathy for a target group that has traditionally been able to afford the required professional counseling. He will also be cautious about importation of nontax fiduciary law (where the role of regulation in the public interest is more linited) and will be inore willing to assume the worst about the motives of grantors of irrevocable inter vivos trusts. Surely, he will share with his friends on the other side of the fence an appropriate degree of outrage at manifestations of incoherence in the present scheine.

In general, the existing rules with respect to fiduciary standards and identity of the trustee (particularly, the inconie tax seginent) ${ }^{144}$

143. Presently, the federal estate tax operates as a real burden on a limited percentage of the population. In 1972, the number of estate tax returns filed that reflected taxable estates represented only $6.1 \%$ of the adult population deaths during the year. S. SURREY, W. WARREN, P. McDaniel \& H. Gutman, Federal. Wealth Transfer Taxation 70 (1977). The increased exemptions reflected in the estate tax credit, I.R.C. $\S 2010$, will further decrease that percentage. In contrast, the federal income tax exacts a toll on a substantial percentage of the population.

144. Even if the tough tax reformer is not able to persuade others of a need to coordinate the transfer and income tax rules, he can defend the toughness of the existing income tax rules by 
seem to come closer to the tough tax reformer's goals than to his opposite's goals. Nevertheless, some sigmificant leaks in the system could be plugged by explicit legislation.

1. Estate Tax. The feature of both sections 2036 (a) and 2038 that excludes from the grantor's gross estate the value of trust assets where he had the foresight to pick a third party trustee seems far too generous. Exclusion from the gross estate seems improper when the trustee is given a broad discretionary power to distribute trust income or primcipal to the grantor. ${ }^{145}$ The imcome tax requirement in section 677(a) that the power at least be shared with a person with a substantial beneficial interest adversely affected by exercise in favor of the grantor ${ }^{146}$ seems preferable to the grantor's ability under sections 2036 and 2038 to secure estate tax exemption by appointment of a third party who has no conceivable pecuniary reason for resisting grantor advice.

Far more debatable is the question whether the "independent trustee" exception of section 674(c) should be adopted for both estate and income tax purposes when the issue is potential grantor benefit. It would not be unreasonable to retain the incoine tax distinction that allows an independent trustee exception in the case of broad powers to control beneficial enjoyment among persons other than the grantor, ${ }^{147}$ but that narrows the exception in the grantor benefit situations to a requirement of sharing with an adverse party. ${ }^{148}$

With respect to administrative powers, the present law would seem unsatisfactory to the tough tax reformer: Congress, by focusing on a single power in the anti-Byrum amendment, has only created an ad hoc exception to the present "common law" interpretation of sections 2036 and $2038 ;^{149}$ and this common law underestimates the degree of control over beneficial enjoyment attributable to the other powers. ${ }^{150}$

\section{Limited Direct Powers Over Beneficial Enjoyment. As dis-}

arguing that the recurring nature of the income tax supplies a greater incentive for tax avoidance by persons in the high income tax category. Thus, the present sophistication of the income tax rules would, in the eyes of such a person, need to be retained even if no substantial changes are made in the transfer tax area.

145. See text accompanying notes 47-60 supra.

146. Treas. Reg. § 1.672(a)-1(a) (1960); see D. KAHN \& L. WAGgoneR, supra note 2, at $622-$ 24.

147. I.R.C. $\$ 674(\mathrm{c})$.

148. Id. $\$ 677$.

149. For a favorable view of the posture of the law outside the Byrum situation, see Gaubatz, supra note 94.

150. See Pedrick 718. Professor Pedrick would assign to the Supreme Court the task of unwinding the damage done by the prior court decisions. Id. 
cussed previously, ${ }^{151}$ both the present estate and incoine tax rules grant a broad exemption when the power of the trustee (even a grantor trustee) over trust income and principal is subject to an ascertainable standard. If the trustee is authorized to distribute trust income or corpus to a beneficiary in such ainounts as he deeins necessary for such beneficiary's "support and maintenance," the trust is not mcluded in the grantor's gross estate ${ }^{152}$ and the mcome will not be taxable to the grantor under section $674(\mathrm{~b})(5)$ (relating to a power over corpus) or under section 674(d) (relatimg to a power over incoine) provided that neither the grantor nor a spouse living with the grantor is one of the trustees. The ascertainable standard exceptions do have major disadvantages: the unwary draftsman has often stumbled into a trap; ${ }^{153}$ the rule has tended to breed hitigation, particularly in the estate tax area; ${ }^{154}$ and in its pure forin (for example, "support and maintenance") the standards may permit too much control over beneficial enjoyınent to allow exclusion when similar nonadministrative powers would require inclusion. ${ }^{155}$

3. Transfer Tax Coordination. For many years, there has been a consensus that the federal transfer tax rules need to be revised in order to prevent a particular transfer from being subject to both the estate and gift tax. ${ }^{156}$ Consequently, any congressional revision of the rules regarding grantor trusts should finally resolve this long standing weakness.

\section{B. More Relaxed Rules.}

A reader may not only rebel against the inconsistency of the existing rules, but may also feel that they are too restrictive because of a different policy perspective. Thoughtful individuals can hardly be expected to object to rules designed to prevent "unearned" estate and in-

151. See text accompanying notes 110-13 supra.

152. E.g., Jennings v. Smith, 161 F.2d 74 (2d Cir. 1947). This case is on the Pedrick list for reconsideration. Pedrick 731 .

153. With respect to whether the property is included under section $204 \mathrm{I}$ in the power holder's gross estate, see, e.g., Franz v. United States, 77-1 U.S.T.C. (CCH) I 13,182 (E.D. Ky. 1977) (relating to decedents' "care, maintenance and welfare").

154. Indeed, one of the reasons for the 1969 adoption of restrictive charitable remainder trust rules was the controversy over ascertainable standards, which had an impact on the amount of the charitable deduction. S. REP. No. 552, 91 st Cong., Ist Sess. 88 (1969), reprinted in [1969] U.S. CODE CONG. \& AD. News 2116.

155. Does a fur coat for the beneficiary fall within the standard? A trip to Europe? Private secondary education? Dancing lessons? The difficulty in administration of the support standard is illustrated by Wyche v. United States, 36 A.F.T.R.2d 75-5816 (Ct. Cl. Tr. Div. 1974), in which the taxpayer prevailed where the issue was taxation to the grantor under section 677(b).

156. See authorities cited in D. KAHN \& L. WAGGONER, supra note 2, at 622-24. 
come tax savings froin an irrevocable inter vivos trust when the retained grantor benefit or control is substantial. Nevertheless, the present tax system might well appear to reflect "overkill" in that underlying assumptions or requirements overlook the possibility-and perhaps the probability - of bona fide performance by most trustees im meeting their primary fiduciary obligation to the beneficiaries. Even more undesirable is the direct incentive, particularly under the income tax rules, to select a trustee who assures tax protection to the grantor at the cost of undesirable nontax consequences. Furthermore, one can argue in favor of a set of rules that does not operate as a significant dismcentive to makmg hifetime gifts. ${ }^{157}$

1. Grantor Benefit Trusts. In general, the advocate of more relaxed tax rules should find it difficult to quarrel with the broad feature of inclusion in the grantor's gross estate under section 2036(a)(1) or with continued grantor taxation on trust mcome under section 677 when the grantor has retained direct and even imdirect benefit from the trust income and corpus. ${ }^{158}$ Indeed, the advocate may even be forced to agree with the tough tax reformer's objection that the apparent estate tax exeinption ${ }^{159}$ when a third-party trustee is given a broad discretionary power to inake distributions to the grantor is too generous. The inequity of this third-party trustee exemption is highlighted by comparmg the estate tax result of two similar trusts. In the first, the third-party trustee has broad discretion in making distributions of income to the grantor and consistently does so for the grantor's support and mamtenance. The trust is excluded from the grantor's gross estate. ${ }^{160}$ In the second trust, the trustee's discretion is limited: he is required to make distributions to the grantor for his support and mamtenance. At least part of the trust will be included in the grantor's gross estate. ${ }^{161}$

On the other hand, section 677(a) overreaches if it taxes the grantor on the entire trust mcome even though his access is expressly limited to an ascertainable standard and the level of trust income is such that some portion of the trust inconse will never be distributed to the

157. Of course, Congress has drifted away from past features of the transfer tax system (i.e., lower gift tax rates and separate transfer taxes) that encouraged hifetime gifts generally. The unification of the estate and gift taxes based upon a single rate scale consciously refiected a partial abandonment of the mcentive philosophy. See H.R. ReP. No. 1380, 94th Cong., 2d Sess. 11 (1976).

158. American Bankers Association, Discussion Draft of Transfer Tax Statute and Explanatory Comments 124, in Public Hearings Before the House Comm. on Ways and Means on General Tax Reform, 93d Cong., 1st Sess., pt. 9, 3747, 3877 (1973).

159. See text accompanying notes $47-60$ supra.

160. See notes $47-48$ supra and accompanying text.

161. See text preceding and accompanying note 19 supra. 
grantor. ${ }^{162}$ A grantor should not be foreclosed from arguing for either estate or mcome tax purposes that his right, including his right under a discretionary power held by a third-party trustee, to trust income and corpus could never encompass the entirety of the trust. ${ }^{163}$

2. Grantor Control Trusts. When the grantor does not have direct or indirect access to trust income and principal for personal benefit, an appealing argument can be made that the existimg rules should not be tightened excessively and should be refined to reflect less cynical assumptions regarding human behavior.

(a) Direct distribution powers. Under sections 2036(a)(2) and 2038, exclusion froin the gross estate whenever the grantor does not, alone or in conjunction with another person, have the power to control beneficial enjoyment is inconsistent with the tighter income tax rules that deal with the reality of "friendly trustees." Perhaps the estate tax exclusion should be limited to situations in which some form of independent trustee test is satisfied. ${ }^{164}$ Whether the exclusion should be expanded to include trusts in which the trustee is an adverse party will be considered below. ${ }^{165}$ With respect to a power subject to an ascertainable standard, a more consistent set of estate and income tax rules should be formulated. The tough tax reformer inight insist that the reconciliation be achieved by incorporating into the estate tax provisions the income tax requirement of section 674(d) that neither the grantor nor a spouse living with him can be one of the trustees. ${ }^{166}$ On the other hand, a broad exemption for powers subject to an ascertainable standard inight be preserved despite uncertainty about its application, ${ }^{167}$ on the ground that a grantor who has a careful draftsman should be rewarded for limiting the grantor's string to the property.

A more radical revision of the present rules would involve the wholesale importation of the various exceptions reflected $\mathrm{m}$ sections 674(b)-(d) into the estate tax area, mcluding the exceptions permitting possession of limited powers by the grantor. ${ }^{168}$ It is not hard to defend

162. See text accompanying notes $24-27$ supra.

163. See text accompanying notes $26-27$ supra.

164. Cf. I.R.C. \$ 674(a) (independent trustee test for income tax purposes).

165. See text accompanying notes 171-80 infra.

166. Such a limitation would change the present estate tax result, where even the grantor can hold the power. Similarly, he can avoid income taxation where the power subject to the ascertainable standard covers invasion of corpus. I.R.C. $\$ 674(\mathrm{~b})(5)$. (Section $674(\mathrm{~d})$ relates only to a power over income.) Some tax reformers have a negative view of even section 674(d). See, e.g., Westfall, supra note 97 , at 345 .

167. See text accompanying notes 110-13 supra.

168. Particularly appealing for incorporation into the estate tax area would be section 
these exemptions if one assumes that the typical trustee will approach the exercise of these limited powers over beneficial enjoyment in a bona fide manner with due regard to fiduciary obligations owed beneficiaries with conflicting interests. For some, allowmg the grantor to be a trustee would be too generous, even if no imdependent trustee requirement similar to that in section 674(c) were mcorporated into the estate tax laws. However, the advocate of a more relaxed approach to trustee powers over beneficial control can point out that some of the present tax rules make assumptions about typical fiduciary behavior not sustained by any known broad contemporary studies. ${ }^{169}$ Preservation of the more restrictive features ${ }^{170}$ of the existimg rules regarding trustee identity might not be justified in the absence of evidence that trustees are deferring on a wholesale and persistent basis to grantor directions or "suggestions."

One feature of the current imcoine tax rules regarding grantor trusts appears initially to be sound in theory, but closer exannination reveals several weaknesses. A grantor can secure protection against incoine taxation by giving the power over beneficial enjoyment to a person who has an interest im the trust that would be adversely affected by exercise of the power. For exainple, an irrevocable inter vivos trust, making $B$ trustee, with income payable to $A$ for life in such amounts as the trustee shall determine and then remainder to $B$ causes no problem for the grantor even if the trustee has a power to revoke the trust and revest the property in the grantor. Section 676(a) would not apply because any exercise by $B$ of the power to revoke would adversely affect his own interest in the trust. ${ }^{171}$

674(b)(7), which permits the temporary withholding of income during a period of a beneficiary's legal disability (including minority). See generally text accompanying notes 117-23 supra. The adverse estate tax result, see text accompanying note 118 supra, would be changed by this proposal. Even some tough tax reformers do not oppose section 674(b)(7). See, e.g., Westfall, supra note 97 , at 336.

169. See J. Dukeminier \& S. Johanson, supra note 116, at 1372 (abuses regarding pension trusts).

170. For example, while the exceptions contained in section 674(b) permit even the grantor or a nonadverse party to be trustee, the limited range of these exceptions and their highly technical features put a pressure on the grantor to utilize the independent trustee exception, section 674(c), which often requires that a bank be included as one of the trustees. The cost of this choice is a disadvantage, particularly where the grantor desires to appoimt a relative who would be willing to serve for no (or at least a reduced) fee. Also, the present rules encourage appointment of a trustee who is an adverse party.

171. Since $B$ also has a power to accumulate income that would be added to corpus distributed to him upon $A$ 's death, neitler the ordinary nor corpus income would be taxable to $G$. $C f$. Treas. Reg. $\$ 1.672(a)-1(d)(1960)$ (the interest of a remainderman is not adverse to the exercise of a power over any income interest preceeding lis remainder). No problem arises under section 674(a) (relating to control over beneficial enjoyınent) because of $B$ 's status as an adverse party. $B$ 
$B$ 's obvious conflict of interest supplies the justification for the tax exemption; the conflict also creates ancillary problems. First, it is very inappropriate for the federal tax laws to include an exception that creates a strong incentive to select the trustee on a basis contrary to preferred trust policies. ${ }^{172}$ Trustees should be selected with a mind towards maximum neutrality in resolving the dehicate and often conflicting interests of various beneficiaries. The problems for the typical fiduciary should not be unnecessarily aggravated by encouraging the negative factor of trustee self-interest.

Traditional trust law places a high priority on the trustee's duty of loyalty to the beneficiaries, which is fortified by tough rules regulating self-dealing behavior by trustees. ${ }^{173}$ The strength of this policy is illustrated by the prohibition in at least one key state of exercise by a trustee of a power over trust imcome or principal for his own benefit. ${ }^{174}$ Furthermore, assigning fiduciary powers to a person with an adverse interest cures the grantor's federal income tax problem at the cost of creating both estate and incoine tax consequences for the holder of the power. The trustee/beneficiary may be deemed to have a general power of appointment for purposes of including a portion of the trust assets in his gross estate, ${ }^{175}$ and the trust income may be taxed to the trustee whether or not distributed to him. ${ }^{176}$ The adverse tax effects to the trustee inay be inadvertently ignored or underestimated by the less experienced practitioner who sees only the "adverse party" exception as a solution for the grantor's income tax problems. ${ }^{177}$ Finally, the application of the adverse party test even for imcome tax purposes can be a tricky busmess, ${ }^{178}$ and the issue of what constitutes a "substantial" adverse interest has had to be litigated in some marginal situations. ${ }^{179}$

Elimination of the adverse party exception in the imcome tax area

would even qualify as an independent trustee, whether or not related to $G$ since section 672(c) defines a related or subordinate party to exclude any adverse party.

172. "The most fundamental duty owed by the trustee to the beneficiaries of the trust is the duty of loyalty." 2 A. ScotT, supra note $21, \S 170$, at 1297.

173. See generally id. $\S 170$.

174. N.Y. Est., Powers \& TRUSTs LAW $\S 10-10.1$ (McKinney 1967). Apparently, this express bar against combining the trustee and beneficiary relationships is not the prevailing view. G. BOGERT, HANDBOOK OF THE LAW OF TRUSTS $§ 30$ (5th ed. 1973).

175. I.R.C. $\$ 2041$.

176. I.R.C. \& 678. See generally Peschel, supra note 95 .

177. For gift tax purposes, a power shared by the grantor with an adverse party will make the transfer a completed gift. Treas. Reg. \$25.2511-2(e) (1958).

178. The regulations, see, e.g., Treas. Reg. $\S 1.672$ (a)-1(b) to l(d) (1960), are sprinkled with several "may be" qualifications that emphasize their nonexhaustive quality.

179. See generally Treas. Reg. § 1.672(a)-1(a) (1960); see also, e.g., Chase Nat'l Bank v. Commissioner, 225 F.2d 621 (8th Cir. 1955); Commissioner v. Katz, 139 F.2d 107 (7th Cir. 1943). 
and resistance to its extension into the estate tax area ${ }^{180}$ on the grounds of strong contrary nontax policy considerations would probably not be a position favored by those who prefer a relaxed approach to federal taxation of grantor trusts. Nevertheless, such a person might see this apparent step backward in pure tax results as a reflection of a better integration of the nontax factors involved in planning these types of trusts.

(b) Administrative powers. Since standard administrative powers held by a trustee (including the grantor) are generally not a major source of estate and incoine exposure for the grantor, ${ }^{181}$ the person advocating a inore relaxed tax scheme for irrevocable inter vivos trusts should be satisfled with the current state of the law. ${ }^{182}$ Of course, the najor exception to this rosy picture is the congressional reversal of the Supreine Court decision in Byrum relating to the retained power to vote corporate stock transferred into trust. ${ }^{183}$ Until the 1978 revision, ${ }^{184}$ the criticisin that the anti-Byrum rule swept too broadly by applying to shares in a corporation not controlled by the grantor was well justified. The broader objection that Congress has made a mistake in isolating one adininistrative power for adverse estate tax treatment is harder to appraise. Certainly, the fact that a grantor would run afoul of the new section 2036(b), ${ }^{185}$ but would be exempt from income taxation under section 675(4) so long as the power to vote is held in a fiduciary capacity (or subject to approval by one in such capacity) does appear to represent another annoying lapse in federal tax coordination. Furthermore, adverse estate tax treatment of the single administrative power in the context of the generous broader tax picture for administrative powers does increase the risk that the careless or less experienced estate planner will make a mistake. An arguinent has been inade that this power to vote shares is not ordinarily retained for the primary purpose of exercising continuing control of the type intended to be proscribed by the present estate and income tax rules. ${ }^{186}$ Perhaps the inost effective defense of the selective treatment of this power is the fact that the grantor retains potential indirect control of beneficial en-

180. See A.L.I., Federal Estate \& Gift Taxation: Recommendations Adopted by the AMERICAN LAW INSTITUTE AND REPORTERS' STUDIES 5, 8 (1969) (recommending extension of the adverse party rule to estate and gift taxation).

181. See text accompanying notes 124-41 supra.

182. The tough tax reformer will typically prefer a tightening in this area. See, e.g., Pedrick.

183. See text accoinpanying notes 133-34 supra.

184. Revenue Act of 1978, Pub. L. No. 95-600, § 702(i), 92 Stat. 2931.

185. Whether the power is held in a fiduciary capacity is irrelevant. S. ReP. No. 745, 95th Cong., 2d Sess. 22 (1978) (pt. II B).

186. Gaubatz, supra note 94 , at 626-27. 
joyment not only for others but also for himself. ${ }^{187}$ Thus, even the more relaxed tax treatment supporter might have to concede that the double-barrel grantor connection might justify this exception.

\section{CONCLUSION}

Any attempt to reahize all or any substantial portion of either the tough tax reform or the more relaxed approach to federal taxation of grantor trusts will require legislative action. Not only are specific features of the present statutory scheme at stake, ${ }^{188}$ but even where possible, ${ }^{189}$ many estate planning professionals will not be enthusiastic about remanding to the Supreme Court reconsideration of the existing rules. ${ }^{190}$ Too much time will be consumed in finishing the project; presumption of a receptive Court's reaction to such a task is debatable; ${ }^{191}$ and the Court's past record is hardly a monument to thoughtful ${ }^{192}$ or consistent ${ }^{193}$ performance.

On the other hand, one should not underestimate the difficulties of a legislative solution. For most members of Congress, the federal tax problems of the wealthy in the area of gratuitous transfers may not be a high priority matter. If the tough tax reform approach is pursued, legislators will be sensitive to the risk of creating an unexpected backlash from a seemingly sound change, as illustrated by their experience with carryover basis for property acquired from a decedent. ${ }^{194}$ The quality

187. For example, the grantor's voting power can be utilized directly or indirectly to provide appointment as an officer or einployee, and to vote dividends on all shares, including those retained by the grantor.

In Byrum, the governunent argued unsuccessfully that both paragraphs (1) and (2) of section 2036 were applicable. 408 U.S. at $131,145$.

188. For instance, the "adverse party" feature of the income tax rules, I.R.C. \& 672(a), and the grantor "alone" or "in conjunction with any other person" feature of the estate tax rules, I.R.C. $\S \S 2036,2038$, are at issue. See text accompanying notes 168 and 180 supra.

189. For example, the meaning of the right "to designate the persons who shall possess or enjoy the property or the income therefrom," I.R.C. $\$ 2036(a)(2)$, could be judicially altered. See text accompanying note 110 supra.

190. For a contrary view, see Pedrick 718.

191. Recently Mr. Justice Blackmun worried that the Court's decision to deny certiorari in Singleton v. Commissioner, 64 T.C. 320 (1975), may have reflected "a natural reluctance to take on another complicated tax case that is devoid of glamour and emotion . . . ."99 S. Ct. 335, 337 (1978).

192. For a discussion of the Court's handling of the grantor's retained life estate problem, see Pedrick 708.

193. Compare United States v. O'Malley, 383 U.S. 627 (1966) with United States v. Byrum, 408 U.S. 125 (1972). Despite efforts at reconciliation in the latter case, both the result and the attitude of the majority are different.

194. The heat froin taxpayers became so intense that Congress, after meffectually thrashing about among various alternatives, simply postponed the effective date for I.R.C. $\$ 1023$ until the end of 1979. Revenue Act of 1978, Pub. L. No. 95-600, § 515, 92 Stat. 2884. 
of the legislative process dealing with the major estate and gift tax revisions in 1976 was poor. ${ }^{195}$ Nevertheless, it seeuns inappropriate to delay reconsideration of a set of rules that have remamed largely untouched for at least a quarter of a century in a form that strikes many observers as riddled with inconsistency and illusion. Estate planning professionals should support review of these rules with an advance commitment to resist the norinal inclination to treat tax revision or reforn as merely a code word for tax reduction.

195. Significant chunks of the estate and gift tax provisions, which were originally contained in a separate bill, H.R. 14844, 94th Cong., 2d Sess. (1976), approved by the House Ways and Means Colnmittee, were simply incorporated in the conference committee version of the final tax bill. The bulky Technical Corrections bill, Pub. L. No. 95-600, $\$ \S 701-703,92$ Stat. 2897 (1978), testifies to the hurried consideration of the 1976 bill that was rushed through Congress as it raced to adjournment in a presidential election year. 


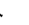

